\title{
Analysis of Reaction Times and Aerobic Capacities of Soccer Players According to Their Playing Positions
}

\author{
Cengiz Taskin ${ }^{1}$, Onder Karakoc ${ }^{2}$, Mine Taskin ${ }^{3}$, Murat Dural ${ }^{4}$ \\ ${ }^{1}$ Batman University, School of Physical Education and Sports, Batman, Turkey \\ ${ }^{2}$ Gaziantep University, School of Physical Education and Sports, Gaziantep, Turkey \\ ${ }^{3}$ Dumlupınar University, Institute of Health Sciences, Kutahya, Turkey \\ ${ }^{4}$ Selcuk University, Institute of Health Sciences, Konya, Turkey \\ Correspondence: Cengiz TASKIN, Batman University, School of Physical Education and Sports, Batman, Turkey.
}

\author{
Received: April 12, 2016 Accepted: April 19, $2016 \quad$ Online Published: April 25, 2016 \\ doi:10.11114/jets.v4i8.1542 URL: http://dx.doi.org/10.11114/jets.v4i8.1542
}

\begin{abstract}
70 soccer players in Gaziantep amateur league voluntarily participated in this study, (average of their ages $19,17 \pm 1,34$ years, average of their heights $181,28 \pm 5,06 \mathrm{~cm}$, average of their body weights $76,75 \pm 4,43 \mathrm{~kg}$ and average of their sports experiences $3,78 \pm 0,95$ years) to analyze visual and auditory reaction times and aerobic capacities of amateur soccer players according to their playing positions. The reaction times against light and sound of right and left hands were measured by 'Newtest Reaction Timer.' The aerobic capacity measurements of players in this study were determined by shuttle sprint test. In comparison of left and right hand reaction times, it was statistically found that goalkeepers had the best reaction times and midfielders had better reaction times than forwards and defenders $(\mathrm{P}<0,05)$. In comparison of aerobic capacities of their playing positions, it was found that $\mathrm{MaxVO} 2$ levels of goalkeepers were lower than that of midfielders and forwards $(\mathrm{P}<0.05)$. In conclusion, it was found that the factors such as MaxVO2 level and reaction time which affect the performances of players nowadays and differ according to their playing positions. It is considered that these differences result from the different training programs according to the playing positions.
\end{abstract}

Keywords: reaction time, aerobic capacity, playing position, soccer

\section{Introduction}

Sports, a significant thing in human life, have an important role for the purpose of recreation and introductory stage of a country. Furthermore, countries with their sports events (Olympic Games, World Championships etc.) introduce themselves and make a profit from organization's finances (Maranci, 1999). Winning a competition in a sports branch is directly related to the number of talented players in the team. For this reason, players with lower skills should do more training to develop their skills. Although talent is a genetic factor, practical and theoretical trainings play an important role to develop skills and techniques. Personal skills and techniques of players used to be significant but today, physical values are more notable. While developing physical quality values, which play an important role in the success, one should not deviate from scientific concepts. Nowadays, soccer has become one of the most important sports activities that countries focus on. As it is mostly watched and attracted all masses, it has become more prominent than other sports branches. Also, durability has a very important role in sports events such as soccer which depends on competition. When oxygen demand increases in the muscles during the sport activities, which has the highest level of physical strength, metabolism should physiologically adapt to this situation. However, the usage of oxygen starts to be limited when the duration and intensity of exercise rise to a certain point and reach the maxVO2 level (Akgun, 1994; Gunay, 1998). A person's maxVO2 level is an important factor among the data that show the levels how good or bad his/her condition is. Obviously, a person's gender, age, body structure, race and environmental factors are among the factors that affect maxVO2 level. MaxVO2 level varies depending on heartbeat volumes, arteria-venous $\mathrm{O} 2$ differences and heart minute frequencies. The excess or shortage of muscle mass, used during the sports activities, is the factor that affects the amount of oxygen consumed per unit of time (Fox and Keteyian, 1988a). The person, who plays soccer that trails the entire world, should be agile, quick and lighter due to the nature of this branch so that $\mathrm{s} / \mathrm{he}$ can be distinguished from his/her opponents in terms of their performances ( Koz and Balci, 2007; Kraemer et al., 2005). Reaction time (Tamer, 2000) described as the time between starting the stimulus and the reaction given to the stimulus, 
is a decisive factor to develop performances in soccer today; is also one of the main factors that provides players to distinguish from their opponents by moving suddenly under the pressure of the opponents, intercepting the balls, and making quick decisions against fakes (Konter, 1997). For this reason, visual and auditory reaction times are very significant criteria in all types of sports branches.

The shortness of the reaction time in sports competitions is the effective factor that distinguishes us from our opponents. Reaction times differ from players who are in the same age and do the same branch (Saitoh, 2006). Challenging less, doing less training, carelessness and over fatigue have negative impacts on our reaction times (Sahin, 1995). The aim of this study is to analyze the comparison of visual and auditory reaction times and MaxVO2 levels of the players according to their playing positions.

\section{Materials and Methods}

70 soccer players in Gaziantep amateur league voluntarily participated in this study, (average of their ages $19,17 \pm 1,34$ years, average of their heights $181,28 \pm 5,06 \mathrm{~cm}$, average of their body weights $76,75 \pm 4,43 \mathrm{~kg}$ and average of their sports experiences $3,78 \pm 0,95$ years). Before measurements, the information was given to players about measurement protocols. Body weight of the players with their sport clothes (shorts-t-shirts and no shoes) were measured by an electronic scale (SECA, Germany) with the accuracy of 0.01 . Their heights were measured by stadiometre (SECA, Germany) with the accuracy of 0.01 (Gordon and his colleagues, 1988).

\subsection{Reaction Test}

The reaction time against light and sound of right and left hand were measured by 'Newtest Reaction Timer.' The players were asked to concentrate on by saying to press the button with their fingers within 3 seconds after the start command. The first 5 measurements were accepted as a try and excluded from the evaluation. Then, discarding the worst and the best values from the 5 measurements, the average of 3 measurements was recorded as the test value. The measurement was recorded in 1/1000 second accuracy. Millisecond was accepted as the value of reaction times.

\subsection{Aerobic Capacity Test}

The aerobic capacities of the players were determined with Shuttle Sprint Test. The players started to run in the form of a round trip of $8 \mathrm{~km} \cdot \mathrm{h}^{-1}$ at a distance of $20 \mathrm{~km}$ by increasing the sprint speed $1 \mathrm{~km} \cdot \mathrm{h}^{-1}$ and sprint speed was determined by a timer with signals at certain intervals. The players were asked to touch the line at the end of the $20 \mathrm{~km}$. When the signal came, the test was ended for the player who did not touch the line twice that was one meter ahead from it and determined the $20 \mathrm{~m}$. line. The rules of the sprint were told to the players and the aerobic power values were determined in the VO2 prediction table according to the shuttle sprint tests (Tamer, 2000).

\subsection{Statistical Analysis}

SPSS 20.00 statistical software package was used for the measurement and the evaluation of the data. Firstly, Kolmogorov Smirnov Normality Test was performed to analyze whether the values of the data had normal distribution or not, then it was observed that the data had normal distribution at the end of the test ( $p>0.05)$. From this perspective, parametric tests were used in the analysis of the data. One way analysis of variance was used in the comparison of visual and auditory reactions according to the positions. To determine which position can cause the differences, Tukey test, one of the multiple comparison tests, was used. In this study, error level was accepted as 0.05 .

\section{Findings}

Table 1. Descriptive statistics of the soccer players in the study

\begin{tabular}{lllll}
\hline \multirow{2}{*}{ Variables } & Goalkeeper $(\mathbf{N}=10)$ & Defender $(\mathbf{N}=\mathbf{3 0})$ & midfielder $(\mathbf{N}=20)$ & Forward $(\mathbf{N}=\mathbf{1 0})$ \\
\cline { 2 - 5 } & Average \pm SD & Average \pm SD & Average \pm SD & Average \pm SD \\
\hline Age $($ year) & $19,60 \pm 1,43$ & $19,10 \pm 1,37$ & $18,90 \pm 1,12$ & $19,10 \pm 1,45$ \\
Height $(\mathrm{cm})$ & $185,10 \pm 4,84$ & $178,73 \pm 5,91$ & $175,10 \pm 5,13$ & $186,20 \pm 4,42$ \\
Body weight $(\mathrm{kg})$ & $81,90 \pm 6,30$ & $73,70 \pm 4,40$ & $72,00 \pm 4,41$ & $79,40 \pm 2,63$ \\
Sports experiences (year $)$ & $3,90 \pm 1,10$ & $4,03 \pm 0,99$ & $3,40 \pm 0,68$ & $3,80 \pm 1,03$ \\
\hline
\end{tabular}

Table 2. The comparison of visual and auditory reaction times and aerobic capacities of the players according to their positions

\begin{tabular}{|c|c|c|c|c|}
\hline \multirow{2}{*}{ Variables } & Goalkeeper $(\mathrm{N}=10)$ & Defender $(\mathrm{N}=30)$ & $\begin{array}{l}\text { Midfielder } \\
(\mathrm{N}=\mathbf{2 0})\end{array}$ & Forward $(\mathrm{N}=10)$ \\
\hline & average \pm SD & average \pm SD & average \pm SD & average \pm SD \\
\hline \multirow{2}{*}{ 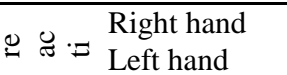 } & $208,97 \pm 14,70^{\mathrm{a}, \mathrm{b}}$ & $266,36 \pm 27,79^{\mathrm{a}, \mathrm{c}}$ & $240,56 \pm 34,49^{\mathrm{c}, \mathrm{d}}$ & $289,14 \pm 50,36^{b, d}$ \\
\hline & $216,09 \pm 9,31^{\mathrm{a}}$ & $277,31 \pm 38,65^{\mathrm{a}}$ & $255,31 \pm 36,50^{\mathrm{a}}$ & $273,48 \pm 48,74^{\mathrm{a}}$ \\
\hline \multirow{3}{*}{$\begin{array}{l}\circlearrowright \mathscr{\sigma}:=\begin{array}{l}\text { Right hand } \\
\text { Left hand }\end{array} \\
\mathrm{MaxVO}_{2} \text { (ml.kg.min) }\end{array}$} & $233,39 \pm 25,53^{\mathrm{a}}$ & $269,36 \pm 43,29$ & $257,31 \pm 30,42$ & $278,44 \pm 41,41^{\mathrm{a}}$ \\
\hline & $243,90 \pm 16,94^{\mathrm{a}, \mathrm{b}}$ & $280,43 \pm 30,52^{\mathrm{a}}$ & $257,88 \pm 33,65^{\mathrm{c}}$ & $290,43 \pm 35,30^{\mathrm{b}, \mathrm{c}}$ \\
\hline & $30,00 \pm 2,79^{\mathrm{a}, \mathrm{d}}$ & $37,91 \pm 5,86^{\mathrm{a}, \mathrm{b}}$ & $45,02 \pm 3,93^{\mathrm{a}, \mathrm{b}, \mathrm{c}}$ & $39,60 \pm 5,44^{\mathrm{d}, \mathrm{c}}$ \\
\hline
\end{tabular}

a, b, c,d: the differences between the averages are significant at the level of $\mathrm{O} .05(\mathrm{P}<0,05)$. 
The comparison of right hand visual reaction times of players according to their positions in table 2, it was found that right hand visual reaction times of goalkeepers are significantly lower than that of defenders and forwards $(\mathrm{P}<0,05)$. In addition to that, it was found that right hand visual reaction times of defenders are significantly higher than that of midfielders and right hand visual reaction times of forwards are significantly higher than that of goalkeepers and midfielders $(\mathrm{P}<0,05)$. Besides, in the comparison of left hand visual reaction times according to playing positions, it was found that left hand visual reaction times of defenders are significantly higher than that of goalkeepers, midfielders and forwards, left hand visual reaction times of forwards are significantly higher than that of goalkeepers and midfielders, and left hand visual reaction times of midfielders are higher than that of goalkeepers $(\mathrm{P}<0,05)$.

In the comparison of right hand auditory reaction times according to positions, it was found that right hand auditory reaction times of forwards are significantly higher than that of goalkeepers $(\mathrm{P}<0,05)$. In the comparison of left hand auditory reaction times according to playing positions, it was found that left hand auditory reaction times of goalkeepers are significantly lower than that of defenders and forwards $(\mathrm{P}<0,05)$. Also, it was found that left hand auditory reaction times of midfielders are lower than that of forwards $(\mathrm{P}<0,05)$.

In the comparison of aerobic capacities according to playing positions, it was found that aerobic capacities of goalkeepers are significantly lower than that of defenders, midfielders and forwards $(P<0,05)$. Also, it was found that aerobic capacities of defenders are significantly lower than that of midfielders $(\mathrm{P}<0,05)$. Furthermore, it was found that aerobic capacities of forwards are significantly lower than that of midfielders $(\mathrm{P}<0,05)$.

\section{Discussion and Conclusion}

This study aims to compare the visual and auditory reaction times and Max VO2 levels of soccer players according to their playing positions in soccer branch. In soccer, one of the challenging sports, a given reaction to a stimulus is mostly related to precognition. Because the reaction time is very significant to fake in tackling, intercept the shots, pass instantly and stop the close-range shots in soccer. This one is also characterized as a precognition skill (Maranci, 1999). The comparison of left hand visual reaction times and right hand visual reaction times according to the playing positions in our study, it was statistically determined that goalkeepers had the best reaction times and the visual and auditory reaction times of midfielders are better than forwards and defenders $(\mathrm{P}<0,05)$.

In his study about the reaction times of goalkeepers of National Handball Team, Asci (2002) determined that the reaction times of goalkeepers are lower than the players of other positions but these values statistically are not significant $(\mathrm{p}<0.05)$. In auditory reaction time measurements, he observed and statistically determined that midfielders are better than goalkeepers $(\mathrm{p}<0.01)$.

In his study about amateur soccer players to show the reaction time values of goalkeepers, defenders, midfielders and forwards, Maranci (1999) determined that the visual and auditory reaction times of goalkeepers are better than the players of other positions. Speed, the important thing for players, requires accelerating after instant stops and changing directions in addition to agility in soccer. Also, intercepting the ball before the opponent in the play indicates that reaction time is an important criterion in soccer. The reaction time, a determinant factor in most sports, can be developed with trainings (Saccuzzo and Michael, 1984). The comparison results according to the playing positions in our study have parallelism with the results of his study. The lower reaction times of goalkeepers than the players of other positions resulted from the importance of precognition for their position and different training programs to develop their agility (Maranci, 1999).

Maximum oxygen consumption (MaxVO2) is the most reliable test to determine maximal aerobic capacity. The high aerobic capacity of the player depends on the oxygen that he/she used per unit of time. The high performance of the player in endurance sports are related to his/her MaxVO2 values (Akgun, 1994). The comparison of the aerobic capacity according to playing positions in our study, it was determined that MaxVO2 levels of goalkeepers are significantly lower than defender, midfielders and forwards $(\mathrm{P}<0,05)$. In a study about male players, MaxVO2 values were found to be $60,9 \mathrm{ml} / \mathrm{kg} / \mathrm{sec}$. for midfielders and 50,1 ml $/ \mathrm{kg} / \mathrm{sec}$. for defenders (Fox and Keteyian, 1988b).

Astrand and Rodahl (1987) determined that MaxVO2 level differs according to sex, body and genetic type, weight and condition of the player. In our study, the reason of the higher MaxVO2 levels of midfielders than that of goalkeepers and the players of other positions is that the players of this position equally contribute both the offence and the defense. Midfielders organize passes by creating free space constantly in a team that plays set offence with short passes. Also, they have to be efficient to score by entering goal box with surprise sprints. We think that their condition levels should be higher as well as MaxVO2 levels because of being the most basic connection between the defense and the offence.

In their study of Galatasaray Youth Team, MaxV02 levels were found to be 55,53 ml/kg/sec. (Bozkurt and Hazar, 2004). In the study of soccer players in second league, MaxV02 levels were found to be $45.83 \mathrm{ml} / \mathrm{kg} / \mathrm{sec}$. (Kayatekin ve ark., 1993). The MaxVO2 levels of Kahramanmarasspor soccer players were found to be $53.12 \mathrm{ml} / \mathrm{kg} / \mathrm{sec}$. (Gencay, 1995). In 
the study of soccer players in third league, MaxV02 levels were found to be $52.4 \mathrm{ml} / \mathrm{kg} / \mathrm{sec}$. (Kaplan et al., 1996).

Analyzing the studies in literature, we consider that higher MaxVO2 levels than the MaxVO2 levels in our study resulted from the players who play in different leagues and the training programs practiced by them. In conclusion, we think that planning different training programs for the physical capacities of the players are significant in terms of reaching the suitable performances for the need of their positions.

\section{References}

Akgun, N. (1994). Egzersiz ve spor fizyolojisi (5. Bask1), Ege Unviversitesi. Basımevi, Cilt 1, Izmir.

Asci, H. (2002). Turkiye erkek hentbol super lig kalecileri ile erkek a milli takım oyuncularinin reaksiyon zamanlarının karsilastırlmasi. Yuksek Lisans Tezi, Gazi Universitesi Saglik Bilimleri Enstitusu Beden Egitimi ve Spor Ana Bilim Dali, Ankara.

Astrand, P. O., \& Rodahl, K. (1987). Textbook of work physiology. Mc Graw-Hill, Singapore, 304-308.

Bozkurt, S., \& Hazar, F. (2004). Ust seviye (elit) genc futbolcularda aerobik dayanıklılık ve fiziksel ozellikleri. The 10th international council for health, physical education, recreation, sport, and dance (ICHPER.SD) \& The tssa 8th international sports science congress Europe Congress (November 17-20) Abstract Book, s. 122, Antalya.

Fox, L. M., \& Keteyian, J. S. (1998a). Fox's physiolojical basis for exercise and sport, methods for anaerobik training and physiologic responses, 268-294, Chapter 11, Sixth Edition.

Fox, L. M., \& Keteyian, J. S. (1998b). Fox's physiolojical basis for exercise and sport, measurement of energy. Work and Power, 72-103, Chapter 4, Sixth Edition.

Gencay, O. (1995). Hazırlik doneminde profesyonel futbolcuların atletik performansinın degerlendirilmesi. Erciyes Universitesi Saglik Bilimleri Enstitusu Yuksek Irtifa ve Spor Bilimleri Yayınlanmamis Yuksek Lisans Tezi, Kayseri.

Gordon, C. C., Chumlea, C. C., \& Roche, A. F. (1988). Stature, recumbent length and weight. Icinde (Eds) Lohman, TG., Roche, AF., Marorell R., Anthropometric standardization reference manual. Illinois, Human Kinetics Books, 3-8.

Günay, M. (1998). Egzersiz fizyolojisi. Kültür Ofset, Ankara, 1998.

Kaplan, T., Tamer, K., \& Karta, R. (1996). Maksimal oksijen tüketiminin futbolda başarıya etkisi. 1. Futbol ve Bilim Kongresi Bildirileri (30 Mayıs-1 Haziran 1996), 44, Izmir.

Kayatekin, M., Semin, I., Oktay, G., Selamoglu, S., Cecen, A., \& Tugay, F. (1993). Bir profesyonel ikinci lig futbol takimının sezon oncesi indirekt maxvo2 degerleri ile demir metabolizmasına iliskin bazı hematolojik parametreler arasındaki ilişkinin araştırılması. Spor Hekimliği Dergisi, 28, 69-76.

Konter, E. (1997). Futbolda süratin teori ve pratiği'. Bağırgan Yayınevi, Ankara, 136-164.

Koz, M., \& Balci, V. (2007). Body size and composition of turkish national american soccer league players. VI th World Congress on Science and Soccer January 15-20, Antalya/Turkey, Book of Abstract, Journal of Sports Science and Medicine, 6(10), 56, http://www.jssm.org.

Kraemer, J. W., Torine, J. C., Silvestre, R., French, D. N., Ratamess, N. A., Spiering, B. A., Hatfield, D. L., Vingren, J. L., \& Volek, J. S. (2005). Body size and composition of national soccer league players. Jornal of Strength and Conditioning Research, 19(3), 485-489. http://dx.doi.org/10.1519/00124278-200508000-00001

Maranc1, B. (1999). Ankara ili Amator ligde mücadele eden futbol kalecileri ile diger mevkilerde bulunan oyuncuların motorik özellikleri, reaksiyon zamanları ve vücut yağ yüzdelerinin karşılaştırılması. Ankara Universitesi Saglik Bilimleri Enstitusu Yuksek Lisans tezi. Ankara.

Saccuzzo, D. P., \& Michael, B. (1984). Speed of information-processing and structurallimitations by retarted and dual-diagnosed, retarted-schizoprenic persons. American Journal of Mental Deficiency, 89, 187-194.

Sahin, R. (1995). Erkek hentbolde kalecilerle saha oyuncularının reaksiyon zamanlarının karsilastirilmasi. Yuksek Lisans Tezi, Gazi Universitesi Sagliık Bilimleri Enstitusu, Beden Eğitimi Spor Ana Bilimdalı, Ankara.

Saitoh, Y. (2006). Recovery from vecuronium is delayed in patients with hyper cholesterolemia. Can J. Anesth, 53, 556-561. http://dx.doi.org/10.1007/bf03021845

Tamer, K. (2000). Sporda fiziksel-fizyolojik performansın ölçülmesi ve değerlendirilmesi. Bagirgan Yayimevi.

\section{(cc) BY}

This work is licensed under a Creative Commons Attribution 3.0 License. 